\title{
Embryonic survival and development at various stages of gestation after bilateral egg transfer in the cow
}

\author{
J. M. Sreenan and D. Beehan \\ The Agricultural Institute, Belclare, Galway, Ireland
}

In sheep, embryonic loss is higher after multiple ovulation than single ovulation (Casida, Woody \& Pope, 1966; Edey, 1966; Mackenzie \& Edey, 1975). Among twin-ovulating sheep, mortality is greater if both ovulations occur from the same ovary (Baier \& Russe, 1968; Scanlon, 1972). Few data are available on the incidence of multiple ovulation in cattle and the extent of prenatal loss in multiple pregnancies is unknown. The development of egg transfer techniques in cattle (Rowson, Moor \& Lawson, 1969) has permitted the establishment of twin pregnancies (Rowson, Lawson \& Moor, 1971; Sreenan, Beehan \& Mulvehill, 1975), and the embryonic survival and development in heifers becoming pregnant after bilateral surgical transfers were therefore examined.

Superovulation, egg recovery and transfer were carried out as previously described (Sreenan et al., 1975). All recipient heifers were checked for return to oestrus with the aid of vasectomized bulls. Initial pregnancy diagnosis was based on heifers not returning to oestrus before transfer. All the heifers were selected on this basis and no attempt was made to diagnose the number of embryos or fetuses present before slaughter or calving. Animals were randomly assigned to the slaughter groups but the facilities available placed a constraint on the number it was possible to slaughter at particular times and groups of unequal size resulted. To determine embryonic survival rate, 39 recipients were slaughtered at $27-30,31-40,41-50$ or 51-117 days of gestation and 13 were allowed to calve. After slaughter, the reproductive tracts were returned to the laboratory immediately and were examined for the presence of embryos. Embryonic weight was selected as being one of the best indicators of development (Prepin, Vigier \& Jost, 1972) and was measured after ligation and section of the umbilical cord as near the abdomen as possible to avoid blood loss. Embryos from which blood was lost were excluded from the results. Analysis related to sex differences was not attempted.

The results in Table 1 show that there was no difference in survival rate of embryos at any of the stages examined. Degenerate embryos were found mainly at the early stages and indicated embryonic mortality before Day 27. Single embryos were slightly heavier at each stage of gestation as reported by Winters, Green \& Comstock (1942), Maneely (1952), and Prepin et al. (1972), although this difference was not marked until calving.

Table 1. Embryonic survival and development in pregnant heifers after bilateral egg transfers

\begin{tabular}{|c|c|c|c|c|c|c|c|c|c|}
\hline \multirow{3}{*}{$\begin{array}{c}\text { Stages of } \\
\text { gestation } \\
\text { (days) }\end{array}$} & \multirow{2}{*}{\multicolumn{2}{|c|}{ No. of embryos }} & \multirow{3}{*}{$\begin{array}{l}\text { No. of } \\
\text { degen- } \\
\text { erate } \\
\text { embryos }\end{array}$} & \multicolumn{6}{|c|}{ Embryo weight (g) } \\
\hline & & & & \multicolumn{3}{|c|}{ Single } & \multicolumn{3}{|c|}{ Twins } \\
\hline & $\begin{array}{l}\text { Trans- } \\
\text { ferred }\end{array}$ & $\begin{array}{c}\text { Surviving } \\
(\%)\end{array}$ & & No. & Mean & Range & No. & Mean & Range \\
\hline $27-30$ & 22 & $19(86)$ & 2 & 3 & $0 \cdot 19$ & $0.16-0.33$ & 8 & $0 \cdot 15$ & $0.09-0.29$ \\
\hline $31-40$ & 36 & $30(83)$ & 4 & 4 & $1 \cdot 19$ & $0 \cdot 30-2 \cdot 35$ & 24 & 0.17 & $0 \cdot 17-2 \cdot 49$ \\
\hline $41-50$ & 12 & $10(83)$ & - & 3 & $2 \cdot 22$ & $2.04-2.47$ & 8 & $2 \cdot 10$ & $1 \cdot 36-3 \cdot 56$ \\
\hline $51-117$ & 8 & $6(75)$ & 1 & 1 & $760 \cdot 00$ & & - & & \\
\hline Calved & 26 & $21(81)$ & - & 5 & 33,360 & $\begin{array}{l}20,450 \\
38,630\end{array}$ & 16 & 28,160 & $\begin{array}{l}19,090 \\
33,180\end{array}$ \\
\hline
\end{tabular}

Total $104 \quad 86(83)$ 
The high embryo survival rate after bilateral transfers is in agreement with the data of Rowson et al. (1971) who found a rate of $82 \%$ in heifers on Day 90 . The greatest loss occurs in fertilized eggs soon after transfer and, once pregnancy is established, uterine capacity does not limit the ability of the cow to carry twins provided they are located in separate uterine horns. Rowson et al. (1971) have shown that embryonic loss is likely if two fertilized eggs are transferred to one uterine horn because transuterine migration is rare in cattle.

We thank Mr A. McDonagh, Mr G. Morris, Mr P. Creaven and Mr B. Bouyssou for help.

\section{References}

BAIER, W. \& Russe, 1. (1968) Embryonic mortality in sheep after double ovulation. Proc. 6th Int. Congr. Anim. Reprod. \& A.I., Paris 1, 397.

CAsIDA, L.E., WoOdY, C.O. \& PoPe, A.L. (1966) Inequality in function of the right and left ovaries and uterine horns of the ewe. J. Anim. Sci. 25, 1169-1171.

EDEY, T.N. (1966) Nutritional stress and preimplantation embryonic mortality in Merino sheep. J. agric. Sci., Camb. 67, 287-293.

Mackenzie, A.J. \& Edey, T.N. (1975) Effects of premating undernutrition on oestrus, ovulation and prenatal mortality in Merino ewes. J. agric. Sci., Camb. 84, 119-124.

ManeeLX, R.B. (1952) Note on the ageing of bovine embryos. Vet. Rec. 35, 509-511.

Prepin, J., Vigier, B. \& Jost, A. (1972) Growth of the calf fetus of single or multiple pregnancies during the period of sexual differentiation (42-70 days).
Annls Biol. anim. Biochim. Biophys. 12, 545558.

Rowson, L.E.A., MooR, R.M. \& LAwson, R.A.S. (1969) Fertility following egg transfer in the cow; effect of method medium and synchronization of oestrus. J. Reprod. Fert. 18, 517-523.

Rowson, L.E.A., Lawson, R.A.S. \& MooR, R.M. (1971) Production of twins in cattle by egg transfer. J. Reprod. Fert. 25, 261-268.

SCANLON, P.F. (1972) Embryo loss and prenatal mortality in sheep. Proc. 7th Int. Congr. Anim. Reprod. \& A.I., Munich 7, 1158-1161.

Sreenan, J.M., Beehan, D. \& Mulvehill, P. (1975) Egg transfer in the cow: factors affecting pregnancy and twinning rates following bilateral transfers. J. Reprod. Fert. 4, 77-85.

Winters, L.M., Green, W.W. \& Comstock, R.E. (1942) Prenatal development of the bovine. Tech. Bull. Minn. agric. Exp. Stn, No. 151.

Received 17 October 1975 